J. Japan. Soc. Hort. Sci. 52(3) : 223-230. 1983.

\title{
Chimerism of Kobayashi-mikan (Citrus natsudaidai $\times$ unshiu) Judged from Isozyme Patterns in Organs and Tissues ${ }^{1}$
}

\author{
Kensuke Yamashita \\ College of Agriculture, Miyazaki University, Miyazaki 880
}

\begin{abstract}
Summary
The present experiment was undertaken to confirm the generally recognized assumption concerning the chimerism of Kobayashi-mikan. This cultivar is supposed to be a synthetic chimera which has arisen from the junction of satsuma mandarin (Citrus unshiu Marc.) scion and Natsudaidai (C.natsudaidai Hayata) stock. Peroxidase and esterase isozymes of foliage and fruit parts as well as immature leaves and rootlets of young seedlings were analyzed by starch gel electrophoresis. The results obtained from a zymographic comparison of Kobayashimikan, satsuma mandarin and Natsudaidai are summarized as follows.

1. In the case of samples taken in July, peroxidase isozyme patterns of new and old leaves as well as albedo of Kobayashi-mikan distinctly resembled those of Natsudaidai. The pattern of juice sac of Kobayashi-mikan considerably resembled that of satsuma mandarin. Esterase isozyme patterns of flavedo and albedo of Kobayashi-mikan were completely the same as those of Natsudaidai.

2. In the case of samples taken in October, peroxidase isozyme patterns of old leaves as well as flavedo of Kobayashi-mikan were nearly the same as those of Natsudaidai. The patterns of albedo and new leaves of Kobayashi-mikan resembled those of Natsudaidai. Esterase isozyme patterns of old leaves and seeds of Kobayashi-mikan were equal to those of Natsudaidai. The patterns of flavedo, alvedo and new leaves of Kobayashi-mikan were rather similar to those of Natsudaidai.

3. Peroxidase and esterase isozyme patterns of immature leaves and rootlets of young seedlings grown from seeds of Kobayashi-mikan were similar to those of young seedlings grown from seeds of Natsudaidai.

From these results, the hypothesis that Kobayashi-mikan is a graft-induced periclinal chimera between satsuma mandarin and Natsudaidai has been further confirmed.
\end{abstract}

\section{Introduction}

In order to clarify the hypothesis that Kobayashi-mikan is a graft-induced periclinal chimera between satsuma mandarin and Natsudaidai, a number of experiments were performed including morphological observations with naked eyes(10), color reaction analysis of bark and leaf extracts $(7,8,9)$, gas chromatographic analysis on the essential oils in leaves(2), and scanning electron microscopic observation on epidermal systems (15). In the present experiment, peroxidase and esterase isozymes in foliage and fruit of Kobayashi-mikan sampled in July and

\footnotetext{
${ }^{1}$ Received for publication October 26, 1982
}

October were examined by starch gel electrophoresis, and the results were compared with those of satsuma mandarin and Natsudaidai. The same procedures were also applied to immature leaves and rootlets of young seedlings grown from seeds of the three cultivars in question.

\section{Materials and Methods}

Mature trees of Kobayashi-mikan (Citrus natsudaidai $\times$ unshiu) in the orchard of $\mathrm{Mr}$. Takemitsu Raisen (Kamikuranaga, Takaokacho, Higashimorokata-gun, Miyazaki Prefecture), Natsudaidai (C.natsudaidai Hayata, CV. 'Kawano') in the orchard of Mr. Torao Nakazuru (Takahama, Takaoka-cho, Higa- 
shimorokata-gun, Miyazaki Prefecture) and satsuma mandarin (C. unshiu Marc., CV. 'Nankan Yongo') in the experimental orchard of Miyazaki University (Funazuka-cho, Miyazaki City, Miyazaki Prefecture) were used as the experimental materials. In July and October, foliage and fruit were sampled, put into polyethylene bags and kept in a freezer at $-18^{\circ} \mathrm{C}$ until used for analysis. In November, immature leaves and rootlets were sampled from young seedlings which had been grown from seeds for a month. Zymographic methods and staining procedures were the same as described in the previous paper(14). Based upon the isozyme patterns obtained, Similarity Index Values between cultivars were calculated as follows: Similarity Index Value (SIV) $=$ Number of bands common to each other/Total number of bands.

\section{Results}

Tables 1 6 show the peroxidase and esterase isozyme patterns of new and old leaves, fruit parts as well as immature leaves and rootlets of young seedlings. Table 7 summarizes the results in Table $1 \sim 6$ so that they can be understood clearly.

1. Zymograms from samples taken in July

Peroxidase isozyme patterns of old leaves and albedo of Kobayashi-mikan were completely the same as those of Natsudaidai. The pattern of new leaves of Kobayashimikan was nearly the same as that of Natsudaidai ( $\mathrm{SIV}=0.933$ ). The pattern of flavedo showed a little difference between the two cultivars $(\mathrm{SIV}=0.625)$. But the pattern of juice sac of Kobayashi-mikan resembled that of satsuma mandarin ( $\mathrm{SIV}=0.778)$.

Table 1. Peroxidase isozyme patterns of foliage and fruit of 'Kobayashi-mikan', 'satsuma' mandarin, and 'Natsudaidai' sampled in July

\begin{tabular}{|c|c|c|c|c|c|c|c|c|c|c|c|c|c|c|c|c|c|}
\hline \multirow{2}{*}{$\begin{array}{l}\text { Organs or Tissues } \\
\text { New leaf }\end{array}$} & \multicolumn{17}{|c|}{ Band Distribution } \\
\hline & $\overline{\mathrm{cm}}$ & $\begin{array}{r}4.2 \sim \\
4.3\end{array}$ & $\begin{array}{r}3.4 \sim \\
3.5\end{array}$ & $\begin{array}{l}3.1 \sim \\
3.3\end{array}$ & $\begin{array}{l}2.5 \sim \\
2.7\end{array}$ & $\begin{array}{r}2.1 \sim \\
2.4\end{array}$ & $\begin{array}{r}1.9 \sim \\
2.0\end{array}$ & $\begin{array}{l}1.5 \sim \\
1.6\end{array}$ & 1. $1 \sim$ & $\begin{array}{r}0.7 \sim \\
0.9\end{array}$ & $\begin{array}{r}0.3 \sim \\
0.4\end{array}$ & $\begin{array}{r}1.7 \sim \\
1.8\end{array}$ & 1. $9 \sim$ & $\begin{array}{r}2.2 \sim \\
2.4\end{array}$ & $\begin{array}{r}2.6 \sim \\
2.7\end{array}$ & $\begin{array}{l}2.8 \sim \\
2.9 \mathrm{c}\end{array}$ & $\begin{array}{l}+ \\
\mathrm{cm}\end{array}$ \\
\hline & $A *$ & + & + & + & - & - & + & - & - & + & + & - & - & + & + & - & \\
\hline & $\mathrm{B}$ & - & - & + & + & + & - & + & + & + & - & - & + & + & - & + & \\
\hline & $\mathrm{C}$ & - & - & + & + & + & - & + & + & + & - & + & + & + & - & + & \\
\hline \multirow[t]{4}{*}{ Old leaf } & $\overline{\mathrm{cm}}$ & $\begin{array}{r}\text { 1. } 9 \sim \\
2.0\end{array}$ & $\begin{array}{r}1.7 \sim \\
1.8\end{array}$ & $\begin{array}{r}1.5 \sim \\
1.6\end{array}$ & $\begin{array}{l}1.3 \sim \\
1.4\end{array}$ & 1. $1 \sim$ & $\begin{array}{r}0.7 \sim \\
0.8\end{array}$ & $\begin{array}{l}0.5 \sim \\
0.6\end{array}$ & $\begin{array}{r}0.2 \sim \\
0.4\end{array}$ & $0 \sim \sim_{0.1}$ & $\frac{0 \sim}{0.1}$ & $\begin{array}{l}1.1 \sim \\
1.2\end{array}$ & $\begin{array}{r}1.5 \sim \\
1.7\end{array}$ & $\begin{array}{r}1.8 \sim \\
2.0\end{array}$ & $\begin{array}{r}2.3 \sim \\
2.5\end{array}$ & $\begin{array}{r}2.6 \sim \\
3.0 \mathrm{c}\end{array}$ & $\begin{array}{l}+ \\
\mathrm{cm}\end{array}$ \\
\hline & $\mathrm{A}$ & - & + & + & - & + & + & + & + & + & + & + & - & + & + & + & \\
\hline & B & + & + & - & + & - & + & - & + & + & + & - & + & + & + & + & \\
\hline & $\mathrm{C}$ & + & + & - & + & - & + & - & + & + & + & - & + & + & + & + & \\
\hline \multirow[t]{4}{*}{ Flavedo } & & & & & - & $\begin{array}{r}2.5 \sim \\
2.8\end{array}$ & $\begin{array}{r}2.0 \sim \\
2.2\end{array}$ & $\begin{array}{l}1.7 \sim \\
1.9\end{array}$ & $\begin{array}{r}0.9 \sim \\
1.1\end{array}$ & $\begin{array}{r}0.3 \sim \\
0.6\end{array}$ & $\begin{array}{r}\text { 1. } 3 \sim \\
1.4\end{array}$ & $\begin{array}{r}2.0 \sim \\
2.4\end{array}$ & $\begin{array}{r}2.5 \sim \\
2.8\end{array}$ & $\begin{array}{l}+ \\
\mathrm{cm}\end{array}$ & & & \\
\hline & A & & & & & - & - & + & + & - & - & + & - & & & & \\
\hline & $\mathrm{B}$ & & & & & + & + & - & + & + & + & + & + & & & & \\
\hline & $\mathrm{C}$ & & & & & + & + & + & - & + & - & + & + & & & & \\
\hline \multirow[t]{4}{*}{ Albedo } & & & & & & $\overline{\mathrm{cm}}$ & $\begin{array}{r}2.5 \sim \\
2.8\end{array}$ & $\begin{array}{l}\text { 1. } 9 \sim 2 \\
2.2\end{array}$ & $\begin{array}{r}1.1 \sim \\
1.2\end{array}$ & $\begin{array}{r}0.5 \sim \\
0.6\end{array}$ & $\begin{array}{r}1.0 \sim \\
1.2\end{array}$ & $\begin{array}{r}2.4 \sim \\
2.7\end{array}$ & $\begin{array}{r}3.3 \sim \\
3.4\end{array}$ & $\begin{array}{r}3.8 \sim \\
3.9\end{array}$ & $\begin{array}{l}+ \\
\mathrm{cm}\end{array}$ & & \\
\hline & $\bar{A}$ & & & & & & - & - & + & + & - & + & - & - & & & \\
\hline & B & & & & & & + & + & - & + & + & + & + & + & & & \\
\hline & $\mathrm{C}$ & & & & & & + & + & - & + & + & + & + & + & & & \\
\hline \multirow[t]{4}{*}{ Juice sac } & & & & & & & $\overline{\mathrm{cm}}$ & $\begin{array}{r}2.6 \sim \\
2.8\end{array}$ & $\begin{array}{r}1.9 \sim \\
2.2\end{array}$ & $\begin{array}{r}0.6 \sim \\
0.8\end{array}$ & $0 \sim$ 0.2 & $\begin{array}{r}0.6 \sim \\
0.9\end{array}$ & 1. $\frac{4 \sim}{1.6}$ & $\begin{array}{r}2.5 \sim \\
2.8\end{array}$ & $\begin{array}{r}3.4 \sim \\
3.5\end{array}$ & 5. $2 \sim$ & \\
\hline & $\mathrm{A}$ & & & & & & & + & + & - & - & - & - & - & + & + & \\
\hline & $\mathrm{B}$ & & & & & & & + & + & + & - & - & - & - & - & + & \\
\hline & $\mathrm{C}$ & & & & & & & + & + & + & + & + & + & + & + & - & \\
\hline
\end{tabular}

A : satsuma mandarin, B : Kobayashi-mikan, C : Natsudaidai 
Table 2. Esterase isozyme patterns of foliage and fruit of 'Kobayashi-mikan', 'satsuma' mandarin and 'Natsudaidai' sampled in July

\begin{tabular}{|c|c|c|c|c|c|c|c|c|c|c|c|c|c|c|c|c|}
\hline \multirow{2}{*}{$\frac{\text { Organs or Tissues }}{\text { New leaf }}$} & \multicolumn{16}{|c|}{ Band Distribution } \\
\hline & $\overline{\mathrm{cm}}$ & $\begin{array}{r}2.0 \sim \\
2.1\end{array}$ & $\begin{array}{r}1.7 \sim \\
1.9\end{array}$ & $\begin{array}{l}1.2 \sim \\
1.4\end{array}$ & $\begin{array}{r}0.4 \sim \\
0.6\end{array}$ & $\begin{array}{l}0.8 \sim \\
1.0\end{array}$ & 1. $2 \widetilde{1.4}$ & $\begin{array}{r}1.7 \sim \\
1.8\end{array}$ & $\begin{array}{r}2.1 \sim \\
2.3\end{array}$ & 2. $4 \sim$ & $2.7 \sim$ & $\begin{array}{l}3.0 \sim \\
3.2\end{array}$ & $\begin{array}{r}3.3 \sim \\
\text { 3. } 4\end{array}$ & $\begin{array}{r}3.7 \sim \\
\quad 3.8\end{array}$ & $\stackrel{+}{\mathrm{cm}}$ & \\
\hline & $A^{*}$ & + & - & + & + & + & + & - & + & - & + & - & + & + & & \\
\hline & $\mathrm{B}$ & - & + & + & + & + & + & + & + & + & + & + & - & - & & \\
\hline & $\mathrm{C}$ & - & + & + & + & + & - & - & + & + & - & + & + & - & & \\
\hline \multirow[t]{4}{*}{ Old leaf } & & - & $\begin{array}{l}0.3 \sim \\
0.6\end{array}$ & $0 \sim$ & $0 \sim$ & $\begin{array}{r}0.2 \sim \\
0.4\end{array}$ & $\begin{array}{l}0.5 \sim \\
0.6\end{array}$ & $\begin{array}{l}0.7 \widetilde{9} \\
0.9\end{array}$ & ${ }_{1.1}^{1.0 \sim}$ & 1. $4 \sim$ & $\begin{array}{r}2.0 \sim \\
2.2\end{array}$ & $\begin{array}{l}2.4 \sim \\
2.6\end{array}$ & $\begin{array}{r}2.7 \widetilde{\sim} \\
2.9\end{array}$ & $\begin{array}{r}3.0 \sim \\
3.2\end{array}$ & 3. $3 \sim$ & $\stackrel{3.5 \sim+}{3.7 \mathrm{~cm}}$ \\
\hline & $\mathrm{A}$ & & + & + & + & + & + & - & + & + & + & + & + & + & + & + \\
\hline & $\mathrm{B}$ & & + & + & + & + & - & + & - & - & - & - & + & + & + & - \\
\hline & $\mathrm{C}$ & & + & + & + & + & + & + & - & - & - & + & + & + & - & + \\
\hline \multirow[t]{4}{*}{ Flavedo } & & & $\overline{\mathrm{cm}}$ & $0.1 \sim$ & $\begin{array}{r}0.3 \sim \\
0.4\end{array}$ & $\begin{array}{l}0.8 \sim \\
0.9\end{array}$ & $\begin{array}{r}1.2 \sim \\
1.6\end{array}$ & $\begin{array}{r}2.2 \sim \\
2.3\end{array}$ & 2. $4 \widetilde{\sigma}$ & $\begin{array}{l}2.7 \sim \\
2.9\end{array}$ & $\begin{array}{r}3.0 \sim \\
\end{array}$ & $\begin{array}{r}3.5 \sim \\
3.9\end{array}$ & $\begin{array}{l}+ \\
\mathrm{cm}\end{array}$ & & & \\
\hline & A & & & - & + & - & - & + & + & - & + & + & & & & \\
\hline & B & & & + & - & + & + & - & - & + & - & + & & & & \\
\hline & $\mathrm{C}$ & & & + & - & + & + & - & - & + & - & + & & & & \\
\hline \multirow[t]{4}{*}{ Albedo } & & & & $0 \sim$ & $\begin{array}{r}0.5 \sim \\
0.6\end{array}$ & $\begin{array}{r}0.8 \sim \\
1.0\end{array}$ & $\begin{array}{r}1.5 \sim \\
1.7\end{array}$ & $\begin{array}{r}2.4 \sim \\
2.6\end{array}$ & 2. $9 \sim$ & $\begin{array}{l}4.0 \sim \\
4.2\end{array}$ & $2 \stackrel{+}{c m}$ & & & & & \\
\hline & $\mathrm{A}$ & & & + & + & - & - & + & - & - & & & & & & \\
\hline & B & & & + & - & + & + & - & + & + & & & & & & \\
\hline & $\mathrm{C}$ & & & + & - & + & + & - & + & + & & & & & & \\
\hline \multirow[t]{4}{*}{ Juice sac } & & & & $0 \sim 0.5$ & $\begin{array}{r}0.5 \sim \\
0.6\end{array}$ & $1.2 \widetilde{1}$ & $\begin{array}{r}1.8 \sim \\
2.0\end{array}$ & $\begin{array}{r}2.8 \sim \\
\quad 3.0\end{array}$ & 4. $2 \sim$ & 9.0 & $5+$ & & & & & \\
\hline & A & & & + & - & - & - & - & - & - & & & & & & \\
\hline & B & & & + & - & + & - & + & + & + & & & & & & \\
\hline & $\mathrm{C}$ & & & + & + & - & + & + & + & + & & & & & & \\
\hline
\end{tabular}

* A : satsuma mandarin, B : Kobayashi-mikan, C : Natsudaidai

The similarity in esterase isozyme patterns is as follows. No difference was observed between Kobayashi-mikan and Natsudaidai in the patterns of flavedo and albedo. The pattern of juice sac of Kobayashi-mikan resembled Natsudaidai a little $(\mathrm{SIV}=0.571)$. But, no similarity in the patterns of new and old leaves was observed on the three cultivars in question.

2. Zymograms from samples taken in October

The peroxidase isozyme patterns of old leaves of Kobayashi-mikan was the same as that of Natsudaidai. Little difference was observed between the patterns of flavedo of Kobayashi-mikan and Natsudaidai (SIV= 0.900). In addition, the two cultivars showed the same tendency in the patterns of albedo (SIV $=0.727$ ). The pattern of new leaves of Kobayashi-mikan was rather similar to that of Natsudaidai (SIV $=0.778$ ). As to the pattern of juice sac, there was no similarity on the three cultivars. The pattern of seeds of Kobayashi-mikan was similar to that of Natsudaidai to some extent (SIV $=0.615)$.

With respect to esterase isozyme patterns, Kobayashi-mikan and Natsudaidai showed the same patterns for old leaves and seeds. They also had similar patterns for new leaves $(\mathrm{SIV}=0.733)$, flavedo $(\mathrm{SIV}=0.700)$ and alvedo $(\mathrm{SIV}=0.818)$. Thus, Kobayashimikan differed from satsuma mandarin completely in the patterns of all organs tested.

3. Zymograms of leaves and rootlets of Young seedlings

Peroxidase and esterase isozyme patterns of immature leaves of young seedlings of Kobayashi-mikan grown from seeds were exactly the same as those of Natsudaidai. The patterns of rootlets of young seedlings 
Table 3. Peroxidase isozyme patterns of foliage and fruit of 'Kobayashi-mikan', 'satsuma' mandarin and 'Natsudaidai' sampled in October

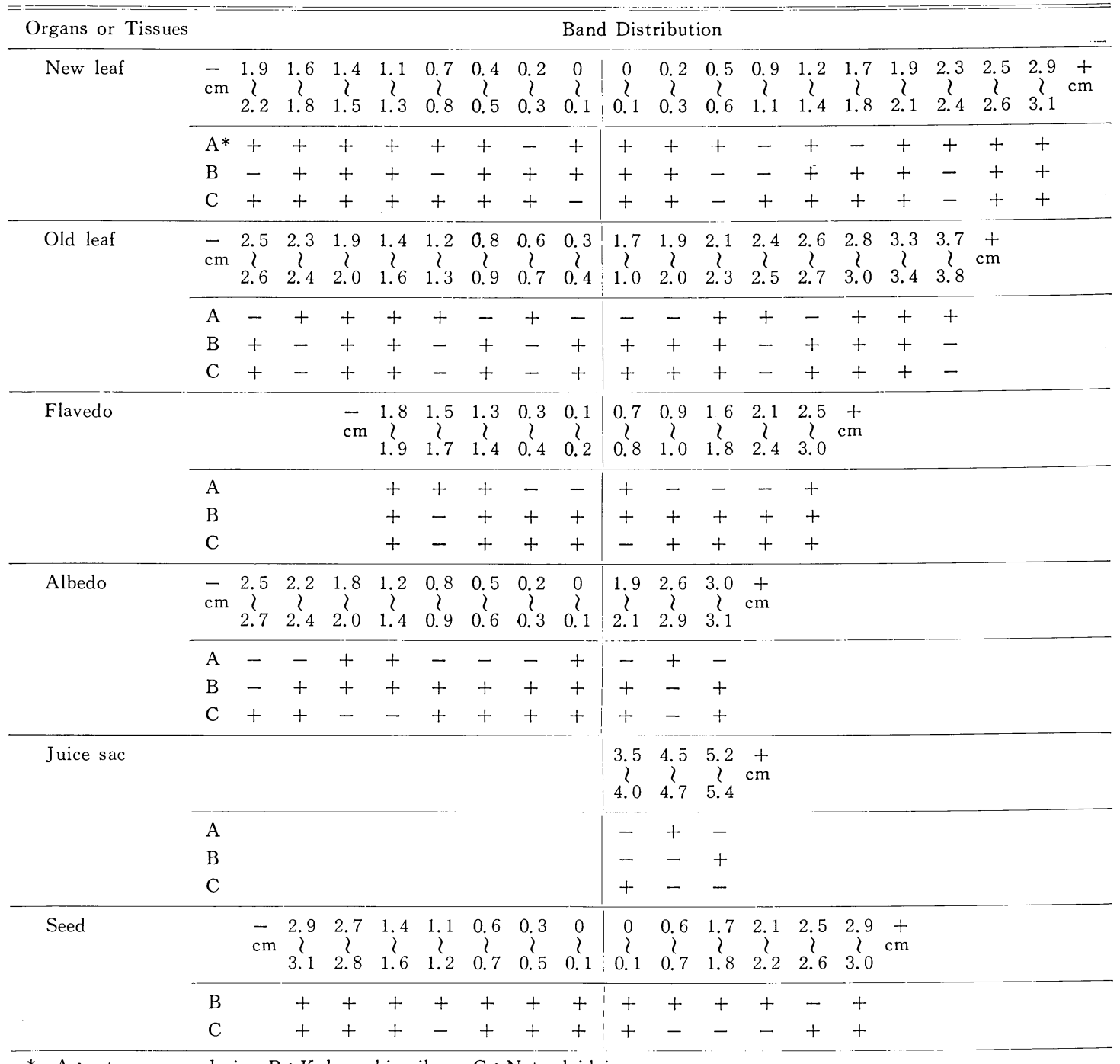

A : satsuma mandarin, B : Kobayashi-mikan, C : Natsudaidai

of the two cultivars were almost the same (SIV of peroxidase and esterase isozyme patterns were 0.818 and 0.900 respectively) and were different from those of rootlets of young seedlings of satsuma mandarin.

\section{Discussion}

Using two kinds of polyploid chimeras whose histogenic layers in the growing point were composed of either $2 n-4 n-4 n$ or $2 n-$ $4 \mathrm{n}-2 \mathrm{n}, \quad$ Frost and $\operatorname{Krug}(1)$ clarified from what layer arises each organ or tissue of a citrus plant. According to their results, epidermal systems arise from the first layer, while the tissue of reproductive organs including ovules and anthers, epidermis of stems, and hypodermal tissues of leaves arise from the second layer. Systematic examination to discover the details of morphological development of fruit tissue has not been carried out using such polyploid chimeras as mentioned above, but Iwamasa(3) stated that epidermis surrounding the whole fruit, as well as flesh itself, arises from the first 
Table 4. Esterase isozyme patterns of foliage and fruit of 'Kobayashi-mikan', 'satsuma' mandarin and 'Natsudaidai' sampled in October

\begin{tabular}{|c|c|c|c|c|c|c|c|c|c|c|c|c|c|c|c|c|}
\hline \multirow{2}{*}{$\frac{\text { Organs or Tissues }}{\text { New leaf }}$} & \multicolumn{16}{|c|}{ Band Distribution } \\
\hline & $\overline{\mathrm{cm}}$ & $0.3 \sim$ & $0 \sim \tilde{0.1}_{1}$ & $0 \sim 0.1$ & $0.2 \sim$ & $\begin{array}{l}0.6 \sim \\
0.7\end{array}$ & $1.1 \sim$ & $\begin{array}{ll}1.3 \sim \\
1.5\end{array}$ & $2.3 \sim$ & $\begin{array}{l}2.6 \sim \\
2.8\end{array}$ & 2. $9 \sim$ & $\begin{array}{r}3.3 \sim \\
3.4\end{array}$ & $3.5 \sim$ & 4. $2 \widetilde{4}$ & $4.7 \widetilde{\sim}$ & $\begin{array}{l}9.2 \sim+ \\
9.4 \mathrm{~cm}\end{array}$ \\
\hline & A & + & + & + & + & + & + & - & + & - & + & + & - & - & - & - \\
\hline & B & + & + & + & + & - & + & + & + & + & + & + & + & - & + & + \\
\hline & $\mathrm{C}$ & + & + & + & + & - & + & + & + & + & + & + & - & + & - & - \\
\hline \multirow[t]{4}{*}{ Old leaf } & & & $\overline{\mathrm{cm}}$ & \multicolumn{13}{|c|}{ 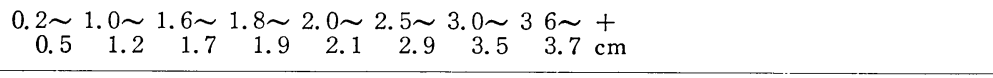 } \\
\hline & A & & & + & - & + & + & + & + & - & + & & & & & \\
\hline & $\mathrm{B}$ & & & + & + & - & - & - & + & + & - & & & & & \\
\hline & $\mathrm{C}$ & & & + & + & - & - & - & + & + & - & & & & & \\
\hline \multirow[t]{4}{*}{ Flavedo } & & & $0 \sim 0.3$ & \multicolumn{13}{|c|}{ 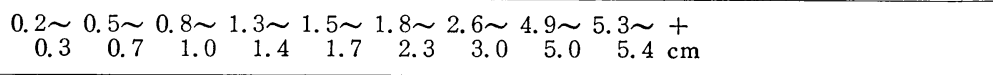 } \\
\hline & $\mathrm{A}$ & & - & - & + & + & - & + & - & + & + & + & & & & \\
\hline & $\mathrm{B}$ & & + & - & + & + & - & - & + & + & - & - & & & & \\
\hline & $\mathrm{C}$ & & + & + & - & + & + & - & + & + & - & - & & & & \\
\hline \multirow[t]{4}{*}{ Albedo } & & $\overline{\mathrm{cm}}$ & $0 \sim$ & \multicolumn{13}{|c|}{ 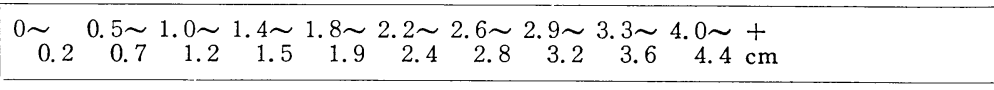 } \\
\hline & A & & - & - & + & + & + & - & - & + & - & + & + & & & \\
\hline & B & & + & + & - & - & - & + & + & - & + & + & + & & & \\
\hline & C & & + & + & - & - & - & - & + & - & + & + & - & & & \\
\hline \multirow[t]{3}{*}{ Seed } & & & & \multicolumn{13}{|c|}{ 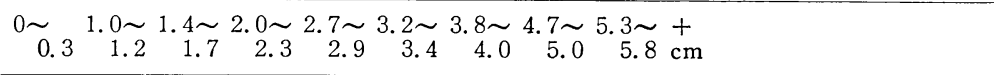 } \\
\hline & $\mathrm{B}$ & & & + & + & + & + & + & + & + & + & + & & & & \\
\hline & $\mathrm{C}$ & & & + & + & + & + & + & + & + & + & + & & & & \\
\hline
\end{tabular}

* A : satsuma mandarin, B : Kobayashi-mikan, C : Natsudaidai

Table 5. Peroxidase isozyme patterns of immature leaves and rootlets of young seedlings of 'Kobayshi-mikan', 'satsuma' mandarin and 'Natsudaidai'

\begin{tabular}{|c|c|c|c|c|c|c|c|c|c|c|c|c|c|c|c|}
\hline \multirow{2}{*}{$\begin{array}{c}\text { Organs or Tissues } \\
\text { Immature leaf }\end{array}$} & \multicolumn{15}{|c|}{ Band Distribution } \\
\hline & & - & $2.3 \sim$ & $1.8 \sim$ & $1.4 \sim$ & $1.0 \sim$ & $0.7 \sim$ & $0 \sim$ & $0 \sim$ & $0.2 \sim$ & $0.7 \sim$ & $1.0 \sim$ & $1.7 \sim$ & $1.9 \sim$ & $2.3 \sim+$ \\
\hline & $\mathrm{A}$ & & + & + & + & + & + & + & + & + & - & + & - & + & + \\
\hline & B & & + & + & - & + & - & + & + & + & + & - & + & + & - \\
\hline & $\mathrm{C}$ & & + & + & - & + & - & + & + & + & + & - & + & + & - \\
\hline \multirow[t]{4}{*}{ Rootlet } & $\overline{\mathrm{cm}}$ & $\begin{array}{r}2.5 \sim \\
2.7\end{array}$ & $1.9 \sim 2$ & $\begin{array}{l}1.5 \sim \\
1.6\end{array}$ & $\begin{array}{r}1.3 \sim \\
1.4\end{array}$ & $\begin{array}{r}1.0 \sim \\
1.2\end{array}$ & $\begin{array}{r}0.8 \sim \\
0.9\end{array}$ & $0 \sim$ & $0 \sim$ & $\begin{array}{l}1.1 \sim \\
1.3\end{array}$ & $\begin{array}{r}1.8 \sim \\
2.0\end{array}$ & $\begin{array}{r}2.1 \sim \\
2.4\end{array}$ & $\begin{array}{l}+ \\
\mathrm{cm}\end{array}$ & & \\
\hline & $\mathrm{A}$ & - & + & - & + & - & + & + & + & - & - & + & & & \\
\hline & $\mathrm{B}$ & + & + & + & + & - & + & + & + & + & + & + & & & \\
\hline & $\mathrm{C}$ & + & + & + & - & + & + & + & + & + & + & + & & & \\
\hline
\end{tabular}

* A : satsuma mandarin, B : Kobayashi-mikan, C : Natsudaidai

layer; flavedo and a part of albedo arise from the second layer; segment, most of albedo, and a part of fruit core arise from the third layer.

Kobayashi-mikan has been supposed to be a periclinal chimera whose first and second layers in the growing point are derived from satsuma mandarin and Natsudaidai, respectively $(10,11)$. If this hypothesis is considered in connection with the explanation on the morphological development of citrus organs or tissues mentioned above, it can be easily 
Table 6. Esterase isozyme patterns of immature leaves and rootlets of young seedlings of 'Kobayashi-mikan', 'satsuma' mandarin and 'Natsudaidai'

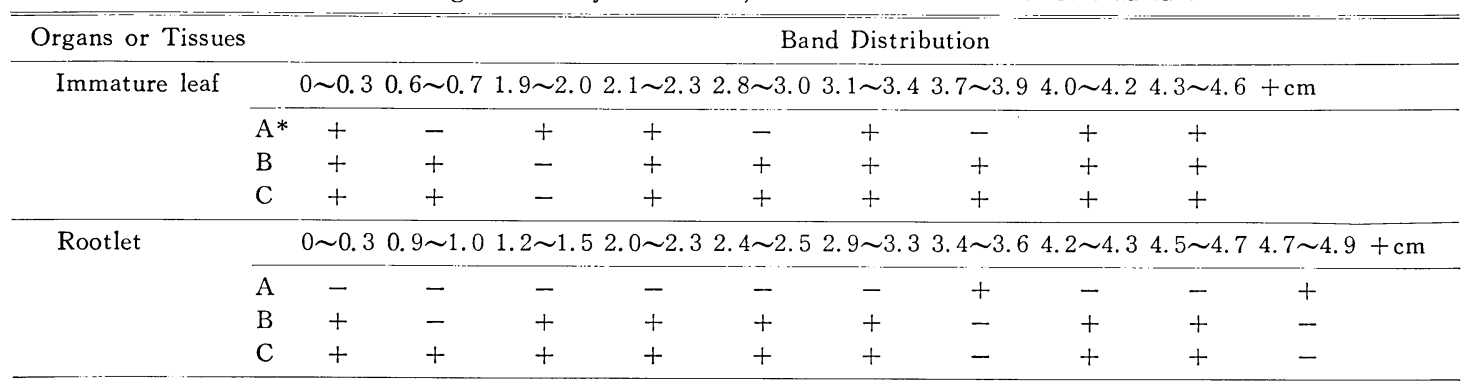

* A : satsuma mandarin, B : Kobayashi-mikan, C : Natsudaidai

Table 7. Similarity Index Values of 'Kobayashi-mikan', 'satsuma' mandarin and 'Natsudaidai' judged from peroxidase and esterase isozyme patterns of organs or tissues

\begin{tabular}{|c|c|c|c|}
\hline $\begin{array}{l}\text { Sampled } \\
\text { Time }\end{array}$ & Organs or Tissues & $\begin{array}{l}\text { Similarity Index Value judged } \\
\text { from peroxidase isozyme patterns }\end{array}$ & $\begin{array}{l}\text { Similarity Index Value judged } \\
\text { from esterase isozyme patterns }\end{array}$ \\
\hline \multirow{10}{*}{ July } & \multirow[t]{2}{*}{ New leaf } & $\mathrm{B} * \sim \mathrm{A}: 0.267$ & $\mathrm{~B} \sim \mathrm{A}: 0.462$ \\
\hline & & $\mathrm{B} \sim \mathrm{C}: 0.933$ & $\mathrm{~B} \sim \mathrm{C}: 0.692$ \\
\hline & \multirow[t]{2}{*}{ Old leaf } & $\mathrm{B} \sim \mathrm{A}: 0.533$ & $\mathrm{~B} \sim \mathrm{A}: 0.786$ \\
\hline & & $\mathrm{B} \sim \mathrm{C}: 1.000$ & $\mathrm{~B} \sim \mathrm{C}: 0.714$ \\
\hline & \multirow[t]{2}{*}{ Flavedo } & $\mathrm{B} \sim \mathrm{A}: 0.250$ & $\mathrm{~B} \sim \mathrm{A}: 0.111$ \\
\hline & & $B \sim C: 0.625$ & $B \sim C: 1.000$ \\
\hline & \multirow[t]{2}{*}{ Albedo } & $\mathrm{B} \sim \mathrm{A}: 0.250$ & $\mathrm{~B} \sim \mathrm{A}: 0.143$ \\
\hline & & $B \sim C: 1.000$ & $\mathrm{~B} \sim \mathrm{C}: 1.000$ \\
\hline & \multirow[t]{2}{*}{ Juice sac } & $\mathrm{B} \sim \mathrm{A}: 0.778$ & $\mathrm{~B} \sim \mathrm{A}: 0.429$ \\
\hline & & $\mathrm{B} \sim \mathrm{C}: 0.333$ & $\mathrm{~B} \sim \mathrm{C}: 0.571$ \\
\hline \multirow{11}{*}{ October } & \multirow[t]{2}{*}{ New leaf } & $\mathrm{B} \sim \mathrm{A}: 0.667$ & $\mathrm{~B} \sim \mathrm{A}: 0.600$ \\
\hline & & $\mathrm{B} \sim \mathrm{C}: 0.778$ & $B \sim C: 0.733$ \\
\hline & \multirow[t]{2}{*}{ Old leaf } & $\mathrm{B} \sim \mathrm{A}: 0.313$ & $\mathrm{~B} \sim \mathrm{A}: 0.250$ \\
\hline & & $B \sim C: 1.000$ & $\mathrm{~B} \sim \mathrm{C}: 1.000$ \\
\hline & \multirow[t]{2}{*}{ Flavedo } & $B \sim A: 0.400$ & $\mathrm{~B} \sim \mathrm{A}: 0.500$ \\
\hline & & $\mathrm{B} \sim \mathrm{C}: 0.900$ & $B \sim C: 0.700$ \\
\hline & \multirow[t]{2}{*}{ Albedo } & $\mathrm{B} \sim \mathrm{A}: 0.364$ & $\mathrm{~B} \sim \mathrm{A}: 0.182$ \\
\hline & & $\mathrm{B} \sim \mathrm{C}: 0.727$ & $\mathrm{~B} \sim \mathrm{C}: 0.818$ \\
\hline & \multirow[t]{2}{*}{ Juice sac } & $\mathrm{B} \sim \mathrm{A}: 0.333$ & $\mathrm{~B} \sim \mathrm{A}:-$ \\
\hline & & $\mathrm{B} \sim \mathrm{C}: 0.333$ & $\mathrm{~B} \sim \mathrm{C}: \quad-$ \\
\hline & Seed & $\mathrm{B} \sim \mathrm{C}: 0.615$ & $\mathrm{~B} \sim \mathrm{C}: 1.000$ \\
\hline \multirow{4}{*}{ November } & \multirow[t]{2}{*}{ Immature leaf of young seedling } & $\mathrm{B} \sim \mathrm{A}: 0.538$ & $\mathrm{~B} \sim \mathrm{A}: 0.556$ \\
\hline & & $\mathrm{B} \sim \mathrm{C}: 1.000$ & $B \sim C: 1.000$ \\
\hline & \multirow[t]{2}{*}{ Rootlet of young seedling } & $\mathrm{B} \sim \mathrm{A}: 0.636$ & $\mathrm{~B} \sim \mathrm{A}: 0.100$ \\
\hline & & $\mathrm{B} \sim \mathrm{C}: 0.818$ & $\mathrm{~B} \sim \mathrm{C}: 0.900$ \\
\hline
\end{tabular}

* A : satsuma mandarin, B : Kobayashi-mikan, C : Natsudaidai

assumed what kind of genetic constitution should be contained in each organ or tissue of Kobayashi-mikan. Based upon this assumption, several chemotaxonomic examinations have been carried out to date, such as zymographic observations by Ueno(12) or Yamashita and Imamura(13). The results of the present experiment show the same tendency as described in the previous reports $(12,13)$ and are likely to fit the assumption for the most part. But, in detail, some of them are a little inconsistent with the assumption. For instance, in October, Similarity Index Value in peroxidase isozyme 
pattern of juice sac was lower than expected between Kobayashi-mikan and satsuma mandarin $(\mathrm{SIV}=0.333)$. In addition, the Similarity Index Values of new leaves of Kobayashi-mikan and Natsudaidai were not always close to 1.000 , although they were more than 0.700 . The reason why they were so is not clear at all, but it is presumably due to some physiological interaction between rind and flesh or between leaf epidermis and mesophyll, whose genetic constitutions are different from each other. Moreover, it might be due to some differences in the stage of the experimental materials used. In fact, some seasonal differences of peroxidase isozymes in peels of satsuma mandarin were pointed out by Kuraoka et al. (6). Thus, the zymographic method is considered to have a limit in deducing the chimerism of plant organs or tissues. Other chemotaxonomic methods tried up to date have not always been sufficient for the same reasons. Therefore, tissue culture should be adopted to obtain more direct and convincing evidence. Tissue blocks should be excised from various parts of the fruit and cultured on a suitable medium in vitro. If a satsuma mandarin plant arises from the callus of juice sac of Kobayashi-mikan and at the same time a Natsudaidai plant from its flavedo callus, it can be conclusive evidence. Based upon these considerations, the author tried tissue culture for two years, where the callus formation was observed only from the block of juice sac. It was extremely difficult to induce a bit of callus from flavedo blocks. But Kato(5) observed the formation of vessels and tracheids in the juice vesicle culture of Hassaku. Since the cells in the juice sac or flavedo of Kobayashi-mikan are sure to have totipotency, there remains a possibility of inducing bud and root formation in the tissue culture of Kobayashi-mikan, provided that some proper auxins, cytokinins and additives are used at favorable concentrations.

\section{Literature Cited}

1. Frost, H. B. and C. A. Krug. 1942. Diploidtetraploid chimeras and bud variants in citrus. Genetics. $27: 619-634$.
2. IKEDA, I. and S. KobAYASHI. 1974. Studies on the leaf oils in citrus breeding (III) Oil composition in graft-induced chimeras. Abstr. Japan. Soc. Hort. Sci. Fall Meeting. 1974 : 88-89. (In Japanese)

3. IWAMASA, M. 1976. Citrus cultivars : 79-81. Citrus Production Union of Shizuoka Prefecture. (In Japanese)

4. KAMISOYAMA, S., S. IWAHORI and J. T. OOHATA. 1981. Cotyledon induction from juice vesicles of Citrus hassaku cultivated in vitro. Mem. Fac. Agr. Kagoshima Univ. $17: 69-70$.

5. KaTO, Y. 1980. Studies on juice vesicles isolated from mature and immature citrus fruit. J. Japan. Soc. Hort. Sci. $47: 437-$ 442.

6. KURAOKA, T., K. IWASAKI AND T. ISHII. 1979. Effects of $\mathrm{GA}_{3}$ and ethephon on the level of $\mathrm{ABA}$ and peroxidase activity in the peel of stasuma mandarin (Citrus unshiu Marc.). J. Japan. Soc. Hort. Sci. $47: 437-442$.

7. Nakamura, M. and K. NAKaYAMA. 1940. Colorimetric test for citrus. Tropical Horticulture $9:$ 199-209. (In Japanese)

8. NAKAMURA, M. and K. NAKAYAMA. 1943. Systematic classification based upon color reaction method with bark extracts. J. Japan. Soc. Hort. Sci. 12:15-23. (In Japanese with English summary)

9. NishiURA, M., J. MatSUShima and N. OKUdaI. 1957. Studies on the identification of citrus species and the descrimination of hybrids from nucellar seedlings. I. Color reaction method with leaf extracts. Bull. National Tokai-Kinki Agr. Exp. Sta. 4:19-26. (In Japanese with English summary)

10. SAmura, R. and K. NaKahara. 1928. Kobayashi-mikan, a graft-induced periclinal chimera between Natsudaidai and satsuma mandarin. Agr. \& Hort. $3: 43-47$. (In Japanese)

11. TAKAHASHI, I. 1972. Citrus. pp. 271-272. Yokendo. Tokyo. (In Japanese)

12. UENO, I. 1974. Peroxidases in leaves of graftinduced chimeras and their seedli ngs in Citrus. Ann. Rep. Hort. Exp. Sta. (Okitsu) in $1973: 4-5$. (in Japanese)

13. YAMASHITA, K. and Y. IMAMURA. 1975. Chimerism of fruit tissues on Kobayashi-m ikan as judged by peroxidase and esterase zymograms. Abst. Spring Meeting Jap. Soc. Hort. Sci. in $1975: 56-57$.

14. Yamashita, K. 1977. A few Physiolog cal and morphological differences of floral and foliar organs between the $2 \mathrm{x}$ and $4 \mathrm{x}$ nats udaidai observed by zymography and scannirg elec- 
tron microscopy. Agr. Bull. Miyazaki Univ. $24: 89-95$.

15. YAMASHITA, K. 1979. Chimerism of Kobayashi-mikan with special reference to its epi- dermal system observed by scanning electron microscopy. J. Japan. Soc. Hort. Sci. 48 : 169-178.

\section{コバヤシミカンのキメラ性に関する研究——特に器官, 組織の \\ アイソザイムパターンについて}

山下研介

宮崎大学農学部 880 宮崎市

\section{摘 要}

本実験においては，ウンシュウミカンとナッダイダイ の接木キメラと葶われているコバヤシミカンを材料とし て, 新・旧葉, 果実, 実生のアイソザイムパターンを観 察し, ウンシュウミカンおよびナツダイダイのそれと比 較した。

1. 7 月の新旧葉, 果実各部位について得られたパー オキシダーゼアイソザイムパターンは, 新・旧葉とアル ベドについてはコバヤシミカンとナッダイダイとの間に はっきりとした類似性がみられた。 しかし，砂じょうに ついては, コバヤシミカンとウンシュウミカンとの間に 類似性がみられた. エステラーゼアイソザイムパターン についてみると，フラベドとアルベドに関してコバヤシ ミカンはナツダイダイと全く同一のパターンを示した.

2. 10月の新旧葉, 果実各部位について得られたパー オキシダーゼアイソザイムパターンについてみると，コ バヤシミカンは旧葉とフラベドに関してナツダイダイと
きわめてよく似たパターンを，またアルベドと新葉に関 してもかなりよく似たパターンを示した. エステラーゼ アイソザイムパターンについてみると, 旧葉と種子に関 してコバヤシミカンとナツダイダイは全く同じパターン を示した. フラベド，アルベド，新葉に関しても，コバ ヤシミカンはナツダイダイに類似したパターンを示し た.

3. 実生の葉および根のパーオキシダーゼおよびェス テラーゼアイソザイムパターンについてみると, コバヤ シミカンはナッダイダイにきわめてよく似たパターンを 示した.

以上の結果より，コバヤシミカンが生長点組織分化層 の第 I 層が温州ミカン因子, 第 II 層がナツダイダイ因子 よりなる周縁キメラであることについて確証が深められ た. 